\title{
Estimating Individual Tree Diameter and Stem Volume Using Airborne LiDAR in Saga Prefecture, Japan
}

\author{
Katsumasa Oono $^{1,2}$, Satoshi Tsuyuki ${ }^{1}$ \\ ${ }^{1}$ Department of Global Agricultural Sciences, The University of Tokyo, Tokyo, Japan \\ ${ }^{2}$ Forest \& Agriculture Solution Department, Asia Air Survey CO., LTD., Kanagawa, Japan \\ Email: ka toono@ajiko.co.jp
}

How to cite this paper: Oono, K., \& Tsuyuki, S. (2018). Estimating Individual Tree Diameter and Stem Volume Using Airborne LiDAR in Saga Prefecture, Japan. Open Journal of Forestry, 8, 205-228. https://doi.org/10.4236/ojf.2018.82015

Received: January 23, 2018

Accepted: April 17, 2018

Published: April 20, 2018

Copyright (c) 2018 by authors and Scientific Research Publishing Inc. This work is licensed under the Creative Commons Attribution International License (CC BY 4.0).

http://creativecommons.org/licenses/by/4.0/

\section{(c) (i) Open Access}

\begin{abstract}
Advancements in airborne LiDAR analysis technology have made it possible to quantify forest resource volumes based on individual trees, and such technology may soon replace field surveys. Unlike individual tree detection or tree height measurements, diameter at breast height (DBH) is difficult to determine directly from measured data and is instead estimated indirectly using the correlation between crown size and DBH. Indicators that represent crown size include crown area, surface area, length, and length ratio, and were utilized with tree height as explanatory variables in ten combinations to determine a regression formula. DBH and tree height calculated from the regression formula were applied to an equation to calculate stem volumes of individual trees. Airborne LiDAR measurements were taken using ALS50-II and ALS60 (Leica) at a density of 4 points $/ \mathrm{m}^{2}$. An evaluation of the relationship between the regression formulae and DBH estimates indicated that a combination of crown area, tree height, and crown ratio for Japanese cedar, and a combination of crown area and tree height for Japanese cypress, yielded the highest coefficients of determination. The average error and RMSE were 6.9\% and $2.38 \mathrm{~cm}$ respectively for Japanese cedar, while the corresponding values for Japanese cypress were $8.35 \%$ and $2.51 \mathrm{~cm}$. Once the relationship was extended to the stem volumes of individual trees, the average error was $14.4 \%$ and RMSE was $0.10 \mathrm{~m}^{3}$ for Japanese cedar. The corresponding values for Japanese cypress were $18.9 \%$ and $0.10 \mathrm{~m}^{3}$. These results demonstrate the potential use of airborne LiDAR as a substitute for field surveys.
\end{abstract}

\section{Keywords}

Airborne LiDAR, Diameter at Breast Height, Individual Treevolume, Forest Resource, Individual-Tree-Based Approach 


\section{Introduction}

Remote sensing can be employed to efficiently survey forest resources. Research using airborne LiDAR has made significant progress recently. For example, LiDAR can be used to determine the location and tree height of individual trees based on their crown height, which is represented by the unevenness in crown size (Hyyppa, 2001; Oono, Numata, \& Hirano, 2008; Popescu, Wynne, \& Nelson, 2002). Individual tree detection is most suitable to conifers because identifying individual crowns is easier than in the case of broad-leaved trees. Importantly, there is a possibility that such detection from laser-based analysis could replace field surveys in Japan, where the percentage of conifers exceeds 50\%. This applicability for Japanese cedar and Japanese cypress is crucial, as they constitute approximately $70 \%$ of all conifers. However, to utilize the method as a substitute for field surveys, estimations of diameter at breast height (DBH) and stem volume are needed in addition to information on the number of trees and tree height.

While DBH cannot be measured directly from airborne remote sensing data, studies have reported a correlation between DBH and crown diameter (Bechtold, 2004; Hemery, Savill, \& Pryor, 2005), and it is possible to indirectly estimate DBH based on remote sensing data. For example, one study used crown diameter and tree height as variables for spruces and pines to estimate DBH using aerial photographs (Hall, Morton, \& Nesby, 1989). A comparison of the results from 12 models showed that DBH estimates can be accurate. A Japanese researcher reported a method for estimating average $\mathrm{DBH}$ per hectare from forest data (e.g., tree height and sparsity) and topographic information (e.g., slopes and altitude, obtained from aerial photographs for major tree species, including Japanese cedar and Japanese cypress) (Nakajima, 1973). To estimate DBH using airborne LiDAR, subsequent studies have estimated DBH by combining characteristics such as crown area and length to determine the relationship between tree crown size and tree height (Verma, Lamb, Reid, \& Wilson, 2014; Yao, Krzystek, \& Heurich, 2012).

While these studies have shown that several explanatory variables can be used to estimate $\mathrm{DBH}$, explanatory variables appropriate for Japanese cedar and Japanese cypress from airborne LiDAR are unknown. In addition, few studies have considered the potential utility of the regression formula used for estimating DBH as a general expression that can be applied across a broad study area, such as an entire prefecture. Therefore, this study considered a regression formula suitable for DBH estimates of Japanese cedar and Japanese cypress, and its use over a broad area. Thus, this work considers appropriate explanatory variables for estimating DBH by performing regression analyses using multiple explanatory variables, such as crown sizes, obtained from airborne LiDAR analysis.

Airborne LiDAR used to estimate stem volumes, an important aspect for managing forest resources sustainably, is broadly divided into two methods. In the first, the stem volume is estimated by performing a regression analysis that 
uses indicators, such as tree height and crown area, included in an arbitrarily given area; these are known as distribution-based approaches (Heurich, Persson, Holmgren, \& Kennel, 2004; Takahashi et al., 2008; Yao, et al., 2012). The other method uses individual-tree-based approaches, in which stem volume is computed by applying tree heights obtained from individual tree detection and DBH estimates obtained from LiDAR analysis to an existing stem volume equation (Heurich, et al., 2004; Hyyppä et al., 2005; Persson, Holmgrem, \& Söderman, 2002). Distribution-based approaches are problematic while using airborne LiDAR as a substitute for conventional field surveys because the stem volumes of individual trees cannot be obtained; this information is obtained from field surveys. To address this problem, this study calculated stem volume based on individual trees, and considered the possibility of assessing resources using airborne LiDAR analysis as a substitute for field surveys. In addition, the study considered the impact of multiple $\mathrm{DBH}$ estimates obtained from $\mathrm{DBH}$ regression analyses for stem volume estimates, and aimed to identify explanatory variables for $\mathrm{DBH}$ estimation appropriate for the estimation of stem volume.

\section{Methods and Data}

\subsection{Study Site and LiDAR Data}

The study area spans 64,000 ha of planted forest in Saga Prefecture, and consists of Japanese cedar and Japanese cypress, which occupy approximately $67 \%$ of the forest area. Most soil in Saga Prefecture is derived from granites in the northern mountainous areas and central part of the prefecture, and lands appropriate for afforestation of Japanese cedar are distributed predominantly over this area. Japanese cypress forest is distributed predominantly in the east where the soil is dry. Clayey soils are distributed predominantly across the southern part of the prefecture, which is appropriate for Japanese cypress. Higashi Matsuura Peninsula is unfavorable for tree growth because of the broad manifestation of basalt lava flow over the plateau, and the soil is strongly clayey with shallow surface soil. Japanese cedar and Japanese cypress dominate Saga Prefecture, and both are major tree species in planted forest. Their complex soil environments provide an advantage in the quantity of forest resources that can be obtained under diverse conditions.

ALS50-II and ALS60 from Leica were used as the airborne LiDAR in this study. LiDAR measurements were taken between July and November 2011 in the Eastern and Western districts. The Eastern district has 483 courses, and the Western, 624 courses, totaling to 1107 courses. The LiDAR measurement density was approximately 4 points $/ \mathrm{m}^{2}$ for both districts.

In the Eastern district, flight height above ground was $800-1500 \mathrm{~m}$, velocity with respect to the ground was $252 \mathrm{~km} / \mathrm{h}$, pulse rate of the laser was 68,000 $80,000 \mathrm{~Hz}$, scan rate was $54-58 \mathrm{~Hz}$ (54 - 58 two-way scans per second), field of view (FOV) was $\pm 12^{\circ}-14^{\circ}$, beam divergence was $0.22 \mathrm{mrad}$, and side overlap ratio was $50 \%$. However, measurements were taken at two different altitudes, 
high and low, in the Western district. For the low altitude measurements, flight height above ground was $1000-1450 \mathrm{~m}$, velocity with respect to the ground was $222 \mathrm{~km} / \mathrm{h}$, pulse rate of the laser was $60,000 \mathrm{~Hz}$, scan rate was $35.9 \mathrm{~Hz}$, field of view was $\pm 18^{\circ}$, beam divergence was $0.22 \mathrm{mrad}$, and side overlap ratio was $60 \%$. For high altitude measurements, flight height above ground was $1231-1981 \mathrm{~m}$, velocity with respect to the ground was $203 \mathrm{~km} / \mathrm{h}$, pulse rate of the laser was $31,000 \mathrm{~Hz}$, scan rate was $46.2 \mathrm{~Hz}$, field of view was $\pm 12.5^{\circ}$, beam divergence was $0.22 \mathrm{mrad}$, footprint size was $27-44 \mathrm{~cm}$, and side overlap ratio was $60 \%$.

A Digital Canopy Surface Model (DCSM) composed of pulses reflected on the canopy surface and Digital Elevation Model (DEM) composed of pulses reflected on the ground surface were created with a $50-\mathrm{cm}$ grid size based on the obtained airborne laser measurement data. The difference between the DCSM and DEM was computed to derive the (Digital Canopy Height Model (DCHM).

\subsection{Study Overview}

Figure 1 shows the data used to estimate DBH and individual tree stem volume in a flow chart of the study. Based on locations of the vertexes of individual trees detected using the method in Oono et al. (2008), and an indicator that represents the unevenness of the crown surface, called the crown shape index (Oono et al., 2008), crowns were delineated using the Watershed algorithm (Soille, 2013). This index was used as the crown area of an individual tree. In addition, crown length, length ratio, surface area, and volume were calculated and utilized, along with tree height, as explanatory variables in the DBH estimates. Field survey results were divided into ten groups of Japanese cedar and Japanese cypress. For nine of the ten groups, regression analyses were performed to estimate DBH. Here, to identify explanatory variables appropriate for estimating $\mathrm{DBH}$, one to three indicators were selected from six indicators for the regression analysis that estimated DBH, for a total of ten patterns. Ten patterns of regression formula

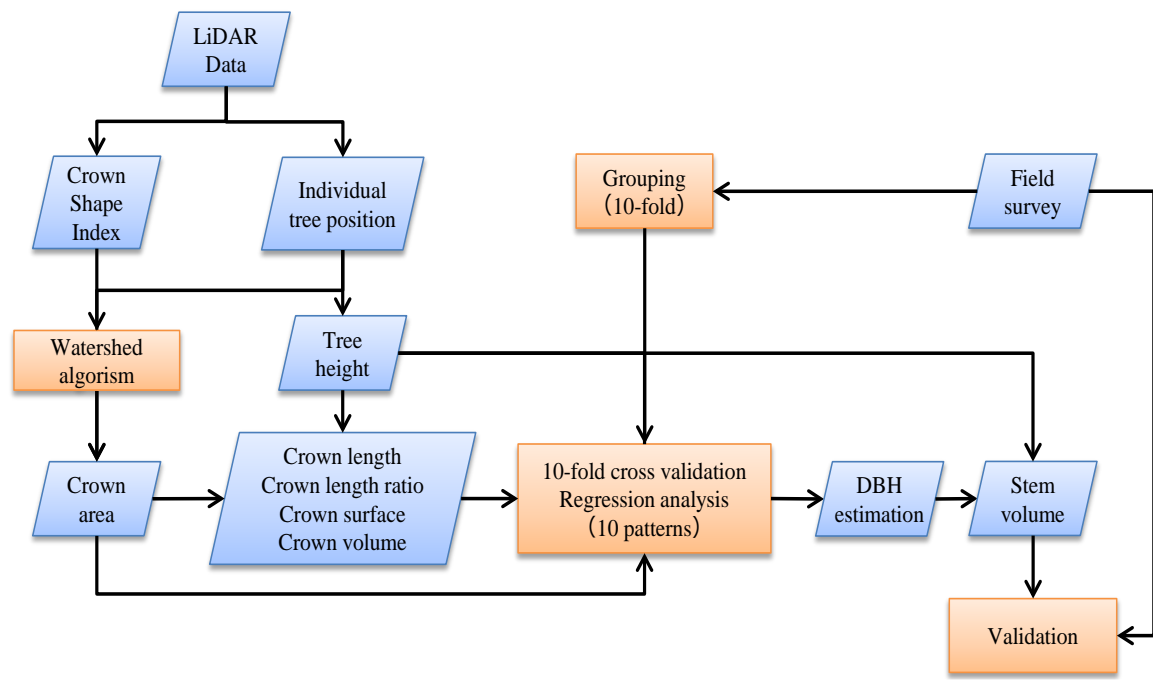

Figure 1. Study flow chart showing the primary steps in the DBH estimation and stem volume calculation. 
were developed, and a total of 100 regression formulae were devised using a10-fold cross-validation. DBH was calculated using the regression formula with the highest coefficient of determination obtained from the respective results. Next, stem volumes of individual trees were calculated from individual tree heights and DBH using the existing volume equation to validate the accuracy.

\subsection{Field Survey Data Used for the Regression Analysis}

Field surveys used for regression analysis validation were conducted at 129 plots for Japanese cedar and 126 plots for Japanese cypress. Field survey points were distributed throughout the prefecture, taking into consideration geological conditions and tree growth stages. The survey period ranged from September 28, 2011 to February 25, 2012, conducted over almost the same period as the airborne LiDAR observations. The survey sites were chosen such that the selected forest stands contained plots of single tree species and there was little variation in tree height or DBH within the plot. A survey at each point was performed for a circular 0.04 ha plot, and the coordinates of the center were measured by GPS. For tree height, a representative tree was measured by VertexIV. Then, the tree height curvature was determined, and the heights of the remaining trees were estimated from the DBH obtained from the field surveys. To calculate stem volume, a volume equation for the Kyushu region (Forestry Agency, 1970) was used and calculated using tree height and DBH as variables. The volume equations are written follows.

- Japanese cedar (excludes Obi and Yakushima, adjusted 1962)

$$
\begin{aligned}
& \log V=-5+0.796182+1.819629 \log d+1.025738 \log h \quad(4 \leq d<32) \\
& \log V=-4+0.0754761+1.66444424 \log d+0.9881512 \log h \quad(32 \leq d)
\end{aligned}
$$

- Japanese cypress (adjusted 1961)

$$
\begin{aligned}
& \log V=-5+0.87211+1.93699 \log d+0.81243 \log h \quad(4 \leq d<12) \\
& \log V=-5+0.682931+1.921617 \log d+1.016795 \log h \quad(12 \leq d<22) \\
& \log V=-5+0.7985347+1.7862040 \log d+1.0696647 \log h \quad(22 \leq d)
\end{aligned}
$$

where $V$ is the stem volume of an individual tree $\left(\mathrm{m}^{3}\right), d$ is the $\mathrm{DBH}(\mathrm{cm})$, and $h$ is the tree height $(\mathrm{m})$. Table 1 is a list of field survey results.

In addition, 129 plots of Japanese cedar and 126 plots of Japanese cypress from the field survey were divided into ten groups with 12 - 13 plots per group, which were used for regression analysis and cross validation. Table 1 shows the field survey information for the divided groups. The average DBH (the objective variable in the regression analysis) per group was $24.6-27.3 \mathrm{~cm}$ for Japanese cedar and $20.2-23.5 \mathrm{~cm}$ for Japanese cypress, and the results for both did not deviate by more than $3 \mathrm{~cm}$. The standard deviation was $3.0-5.6$ for Japanese cedar and 3.7 - 5.4 for Japanese cypress. These results indicate that the regression formula can be evaluated under similar conditions due to the small deviation. 
Table 1. Characteristics of survey plots and ten-fold plots.

\begin{tabular}{|c|c|c|c|c|c|c|c|c|c|c|c|}
\hline & \multicolumn{5}{|c|}{ Japanese cedar $(n=129)$} & \multicolumn{5}{|c|}{ Japanese cypress $(\mathrm{n}=126)$} \\
\hline & & \multirow{2}{*}{$\begin{array}{c}\text { All } \\
\text { plots }\end{array}$} & \multicolumn{4}{|c|}{ Ten-fold plots } & \multirow{2}{*}{$\begin{array}{c}\text { All } \\
\text { plots }\end{array}$} & \multicolumn{4}{|c|}{ Ten-fold plots } \\
\hline & & & Average & Min & Max & SD & & Average & Min & $\operatorname{Max}$ & SD \\
\hline \multirow{4}{*}{ Trees/ha } & Average & 1.220 & 1.219 & 1.085 & 1.344 & 82 & 1.323 & 1.324 & 1.108 & 1.490 & 121 \\
\hline & Minimum & 400 & 618 & 400 & 850 & 153 & 450 & 640 & 450 & 825 & 125 \\
\hline & Maximum & 2.925 & 2.018 & 1.525 & 2.925 & 420 & 2.700 & 2.285 & 1.550 & 2.700 & 332 \\
\hline & $\mathrm{SD}$ & 411 & 385 & 240 & 596 & 116 & 499 & 477 & 307 & 568 & 83 \\
\hline \multirow{4}{*}{$\begin{array}{l}\text { Tree } \\
\text { height } \\
(\mathrm{m})\end{array}$} & Average & 19.1 & 19.1 & 18.5 & 19.6 & 0.3 & 16.2 & 16.2 & 15.8 & 16.7 & 0.2 \\
\hline & Minimum & 8.4 & 13.1 & 8.4 & 14.7 & 1.8 & 7.9 & 10.1 & 7.9 & 11.4 & 1.0 \\
\hline & Maximum & 25.4 & 23.6 & 22.4 & 25.4 & 0.9 & 24.8 & 21.8 & 20.0 & 24.8 & 1.8 \\
\hline & $\mathrm{SD}$ & 2.7 & 2.7 & 2.1 & 3.6 & 0.3 & 3.0 & 3.0 & 2.5 & 3.4 & 0.4 \\
\hline \multirow{4}{*}{$\begin{array}{c}\text { Crown } \\
\text { length } \\
(\mathrm{m})\end{array}$} & Average & 3.7 & 3.6 & 2.8 & 4.7 & 0.6 & 3.3 & 3.3 & 2.9 & 3.8 & 0.2 \\
\hline & Minimum & 1 & 1.2 & 1.0 & 2.0 & 0.4 & 1 & 1.2 & 1.0 & 2.0 & 0.4 \\
\hline & Maximum & 10.1 & 8.1 & 4.7 & 10.1 & 2.0 & 8.9 & 7.1 & 5.5 & 8.9 & 1.0 \\
\hline & SD & 2.0 & 1.8 & 1.0 & 2.7 & 0.5 & 1.7 & 1.6 & 1.3 & 2.3 & 0.3 \\
\hline \multirow{4}{*}{$\begin{array}{l}\mathrm{DBH} \\
(\mathrm{cm})\end{array}$} & Average & 25.8 & 25.8 & 24.6 & 27.3 & 0.8 & 22.0 & 22.0 & 20.2 & 23.5 & 0.9 \\
\hline & Minimum & 13 & 18.6 & 13.0 & 22.0 & 3.0 & 12 & 14.2 & 12.0 & 16.0 & 1.2 \\
\hline & Maximum & 39 & 34.3 & 30.0 & 39.0 & 2.5 & 37 & 30.6 & 24.0 & 37.0 & 3.8 \\
\hline & $\mathrm{SD}$ & 4.3 & 4.1 & 2.9 & 5.4 & 0.8 & 4.6 & 4.4 & 3.5 & 5.2 & 0.6 \\
\hline \multirow{4}{*}{$\begin{array}{c}\text { Stem } \\
\text { volume } \\
\left(\mathrm{m}^{3} / \mathrm{ha}\right)\end{array}$} & Average & 585 & 584 & 514 & 650 & 39 & 412 & 412 & 364 & 445 & 23 \\
\hline & Minimum & 175 & 312 & 175 & 400 & 82 & 111 & 164 & 111 & 242 & 40 \\
\hline & Maximum & 1.026 & 877 & 767 & 1.026 & 86 & 1.089 & 751 & 558 & 1.089 & 171 \\
\hline & SD & 161 & 153 & 122 & 227 & 28 & 166 & 161 & 115 & 239 & 35 \\
\hline
\end{tabular}

\subsection{Explanatory Variables Used in the Regression Formula to Estimate DBH}

For the regression formula to estimate $\mathrm{DBH}$, six explanatory variables were prepared, including tree height, and indicators of crown size, including crown area, surface area, volume, length, and length ratio. For $\mathrm{h}(\mathrm{m})$, individual tree height determined using the method described in Oono et al. (2008) was used. Crown area $\mathrm{Ca}\left(\mathrm{m}^{2}\right)$ was extracted by inverting the crown shape index, treating the tree vertex as the lowest point in the crown, and the crowns were delineated using the Watershed algorithm from individual tree detection results. Crown delineation was performed as shown Figure 2.

Crown length $\mathrm{Cl}(\mathrm{m})$ was calculated from the difference between the maximum and minimum DCHM values within a single crown area. Figure 3 shows an example calculation of crown length. In addition, using tree height $\mathrm{h}$ and $\mathrm{Cl}$, the crown length ratio $C r(\%)$ was calculated using Equation (3).

$$
C r=\frac{C l}{h} \times 100
$$




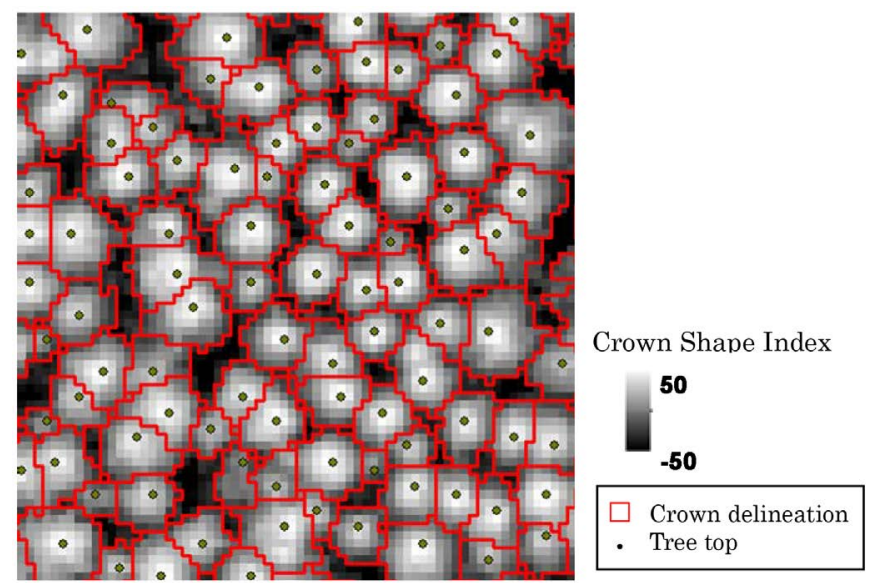

Figure 2. Example of crown delineation using the watershed algorithm (1 pixel: $50 \mathrm{~cm}$ ).

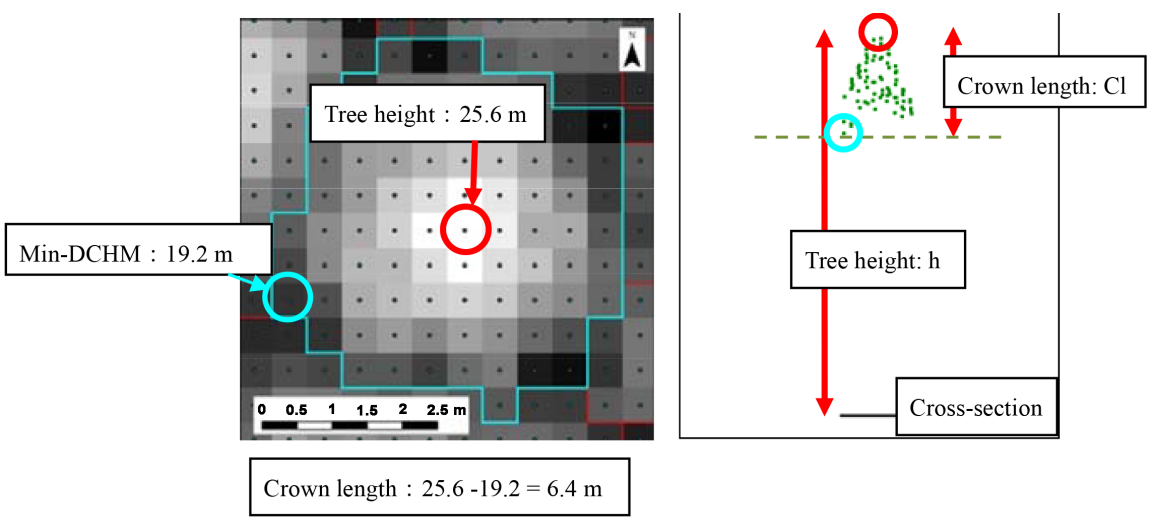

Figure 3. Example of crown length calculation; points in the left figure show the DCHM and match points corresponding to the crown shape in the right cross-section.

The crown surface area $C s a\left(\mathrm{~m}^{2}\right)$ and crown volume $C_{V}\left(\mathrm{~m}^{3}\right)$ were calculated assuming that tree crowns are conical. Based on the approach shown in Figure 4, the crown surface area was calculated from crown area and crown length using Equation (4). Crown volume was calculated using Equation (5).

$$
\begin{aligned}
2 \pi R \frac{\theta}{360}=2 \pi r \text { and } \frac{\theta}{360}=\frac{r}{R} \\
C a=\pi r^{2} \text { and } r=\sqrt{\frac{C a}{\pi}} \\
r^{2}+C l^{2}=R^{2} \text { and } R=\sqrt{r^{2}+C l^{2}}=\sqrt{\frac{C a}{\pi}+C l^{2}}=\sqrt{\frac{C a+\pi C l^{2}}{\pi}} \\
C s a=\frac{\theta}{360} \pi R^{2} \\
=\pi r R \\
=\pi \sqrt{\frac{C a}{\pi} \sqrt{\frac{C a+\pi C l^{2}}{\pi}}} \\
=\sqrt{C a\left(C a+\pi C l^{2}\right)}
\end{aligned}
$$




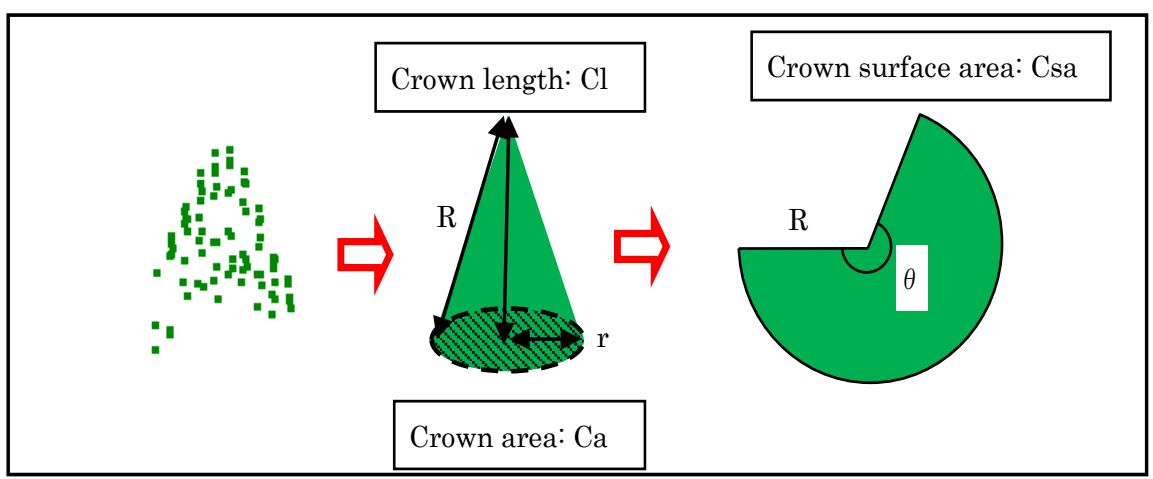

Figure 4. Method used to calculate the crown surface.

where $\theta$ is the center angle $\left({ }^{\circ}\right)$ of the sector from conical tree crown, $R$ is the radius of conical slope length $(\mathrm{m})$, and $r$ is the radius of the bottom of the cone (m).

$$
C v=\frac{C a \times C l}{3}
$$

\subsection{Regression Analysis and Stem Volume Calculation Methods to Estimate DBH and Validate the Accuracy}

The regression analysis was validated ten times using ten-fold cross validation, and ten patterns of regression formula were developed each time. A total of 100 regression formulae were developed. Nine of the ten groups of field survey plots (Japanese cedar: 116 - 117 plots, Japanese cypress: 113 - 114 plots) were used to develop regression formulae, and the remaining group was used to validate accuracy. Equation (6) was used to determine the regression formula, which was based on the allometry theory (Ketterings, Coe, van Noordwijk, Ambagau', \& Palm, 2001; Nielsen, Aldred, \& MacLeod, 1979).

$$
D B H=\alpha X_{1}^{\beta 1} X_{2}^{\beta 2} X_{3}^{\beta 3}
$$

Where $X$ represents individual explanatory variables. Ten patterns of regression formula were considered using combinations of one to three explanatory variables hypothesized as ideal to estimate DBH. $X_{2}$ and $X_{3}$ were not used for cases in which only one explanatory variable was applied.

Combinations of explanatory variables across ten patterns are shown in Table 2, which were based first on tree crown size, and then combined with tree height. The tree crown height information, including tree height, crown length, and crown length ratio were combined with crown area.

$\mathrm{DBH}$, the objective variable of regression formula, was calculated using the average value from field survey plots. The average value was calculated per plot for individual tree crown area, an explanatory variable, obtained from LiDAR analysis, and a regression analysis was performed using the average survey plot value. DBH for an individual tree was computed by substituting the group explanatory variable preserved for accuracy validation into the regression formula with the highest coefficient of determination; the accuracy was validated by 
Table 2. Pattern of explanatory variables for the regression analysis.

\begin{tabular}{ccc}
\hline Regression formula & & Pattern of explanatory variables \\
\hline 1 & $\mathrm{X}_{1}$ & Crown area \\
2 & $\mathrm{X}_{1}$ & Crown surface \\
3 & $\mathrm{X}_{1}$ & Crown volume \\
& $\mathrm{X}_{1}$ & Crown area \\
& $\mathrm{X}_{2}$ & Tree height \\
& $\mathrm{X}_{1}$ & Crown surface \\
& $\mathrm{X}_{2}$ & Tree height \\
& $\mathrm{X}_{1}$ & Crown volume \\
& $\mathrm{X}_{2}$ & Tree height \\
& $\mathrm{X}_{1}$ & Crown area \\
$\mathrm{X}_{2}$ & Crown length \\
7 & $\mathrm{X}_{1}$ & Crown area \\
& $\mathrm{X}_{2}$ & Crown length ratio \\
& $\mathrm{X}_{1}$ & Crown area \\
$\mathrm{X}_{2}$ & Tree height \\
$\mathrm{X}_{3}$ & Crown length \\
& $\mathrm{X}_{1}$ & Crown area \\
$\mathrm{X}_{2}$ & Tree height \\
$\mathrm{X}_{3}$ & Crown length ratio \\
& & \\
& &
\end{tabular}

calculating the average plot $\mathrm{DBH}$. Using this validation process, ten regression formula patterns were obtained from the 100 patterns.

To calculate the stem volume of an individual tree, the volume equation (formulae 1 and 2) from the Kyushu region (Forestry Agency, 1970) was used based on individual tree height and estimated $\mathrm{DBH}$ obtained from airborne $\mathrm{Li}$ DAR analysis. To validate the stem volume, the average individual stem volumes $\left(\mathrm{m}^{3}\right)$ from surveyed plots was calculated and compared with individual tree stem volumes from field surveys and LiDAR analysis.

\section{DBH Estimates Using Tree Crown and Height Data, and Individual Stem Volume Estimates}

\subsection{DBH Estimates}

Table 3 and Table 4 show the results from ten regression analysis patterns using ten-fold cross validation for Japanese cedar and Japanese cypress. A high coefficient of determination (corrected $\mathrm{R}^{2}$ ) was found for the crown surface area, volume, and area for regression formula using a single explanatory variable for both Japanese cedar and Japanese cypress. The coefficient of determination increased in regression formulae $4-6$, where tree height was added, although the differences in coefficients of determination were not significant, all $\sim 0.7$. In contrast, for regression formulae 1 - 3, only a single explanatory variable was used. However, compared to regression formula 1, which used crown area alone, the coefficient of determination did not improve in regression formula 7 , wherein the crown length was added to crown area and yielded a similar value, while the 
Table 3. Results of regression analysis for DBH estimation (Japanese cedar).

\begin{tabular}{|c|c|c|c|c|c|c|c|}
\hline & Explanatory variable & & $\alpha$ & $\beta 1$ & $\beta 2$ & $\beta 3$ & Adjusted $\mathrm{R}^{2}$ \\
\hline \multirow{4}{*}{$\begin{array}{l}\text { Regression } \\
\text { formula } 1\end{array}$} & \multirow{4}{*}{$\mathrm{X}_{1}$ : Crown area } & Average & 9.6092 & 0.4632 & & & 0.6324 \\
\hline & & Minimum & 9.1265 & 0.4367 & & & 0.5875 \\
\hline & & Maximum & 10.2193 & 0.4888 & & & 0.6524 \\
\hline & & $\mathrm{SD}$ & 0.3124 & 0.0145 & & & 0.0188 \\
\hline \multirow{4}{*}{$\begin{array}{l}\text { Regression } \\
\text { formula } 2\end{array}$} & \multirow{4}{*}{$\mathrm{X}_{1}$ : Crown surface area } & Average & 12.8289 & 0.2071 & & & 0.4399 \\
\hline & & Minimum & 12.4174 & 0.1967 & & & 0.3949 \\
\hline & & Maximum & 13.3491 & 0.2165 & & & 0.4777 \\
\hline & & SD & 0.3059 & 0.0063 & & & 0.0235 \\
\hline \multirow{4}{*}{$\begin{array}{l}\text { Regression } \\
\text { formula } 3\end{array}$} & \multirow{4}{*}{$\mathrm{X}_{1}$ : Crown volume } & Average & 15.9813 & 0.1704 & & & 0.4946 \\
\hline & & Minimum & 15.6750 & 0.1608 & & & 0.4529 \\
\hline & & Maximum & 16.4873 & 0.1766 & & & 0.5272 \\
\hline & & $\mathrm{SD}$ & 0.2779 & 0.0052 & & & 0.0215 \\
\hline \multirow{4}{*}{$\begin{array}{l}\text { Regression } \\
\text { formula } 4\end{array}$} & \multirow{4}{*}{$\begin{array}{l}\mathrm{X}_{1} \text { : Crown area } \\
\mathrm{X}_{2} \text { : Tree height }\end{array}$} & Average & 4.7868 & 0.3779 & 0.2992 & & 0.7158 \\
\hline & & Minimum & 4.4752 & 0.3569 & 0.2538 & & 0.6883 \\
\hline & & Maximum & 5.5837 & 0.3967 & 0.3186 & & 0.7343 \\
\hline & & SD & 0.3078 & 0.0113 & 0.0179 & & 0.0137 \\
\hline \multirow{4}{*}{$\begin{array}{l}\text { Regression } \\
\text { formula } 5\end{array}$} & \multirow{4}{*}{$\begin{array}{c}\mathrm{X}_{1} \text { : Crown surface area } \\
\mathrm{X}_{2} \text { : Tree height }\end{array}$} & Average & 3.7795 & 0.1734 & 0.4549 & & 0.6737 \\
\hline & & Minimum & 3.5521 & 0.1685 & 0.4133 & & 0.6450 \\
\hline & & Maximum & 4.3115 & 0.1791 & 0.4706 & & 0.6930 \\
\hline & & SD & 0.2105 & 0.0037 & 0.0162 & & 0.0154 \\
\hline \multirow{4}{*}{$\begin{array}{l}\text { Regression } \\
\text { formula } 6\end{array}$} & \multirow{4}{*}{$\begin{array}{l}\mathrm{X}_{1} \text { : Crown volume } \\
\mathrm{X}_{2} \text { : Tree height }\end{array}$} & Average & 5.0669 & 0.1399 & 0.4203 & & 0.6880 \\
\hline & & Minimum & 4.7812 & 0.1347 & 0.3794 & & 0.6617 \\
\hline & & Maximum & 5.7777 & 0.1448 & 0.4365 & & 0.7072 \\
\hline & & $\mathrm{SD}$ & 0.2789 & 0.0033 & 0.0160 & & 0.0147 \\
\hline \multirow{4}{*}{$\begin{array}{l}\text { Regression } \\
\text { formula } 7\end{array}$} & \multirow{4}{*}{$\begin{array}{c}\mathrm{X}_{1}: \text { Crown area } \\
\mathrm{X}_{2}: \text { Crown length }{ }^{*}\end{array}$} & Average & 9.7154 & 0.4472 & 0.0146 & & 0.6304 \\
\hline & & Minimum & 9.1699 & 0.4206 & 0.0034 & & 0.5872 \\
\hline & & Maximum & 10.2433 & 0.4813 & 0.0254 & & 0.6507 \\
\hline & & SD & 0.3143 & 0.0164 & 0.0074 & & 0.0185 \\
\hline \multirow{4}{*}{$\begin{array}{l}\text { Regression } \\
\text { formula } 8\end{array}$} & \multirow{4}{*}{$\begin{array}{l}\mathrm{X}_{1} \text { : Crown area } \\
\mathrm{X}_{2} \text { : Crown length } \\
\text { ratio* }\end{array}$} & Average & 10.0781 & 0.4889 & -0.0316 & & 0.6362 \\
\hline & & Minimum & 9.7027 & 0.4645 & -0.0379 & & 0.5891 \\
\hline & & Maximum & 10.7685 & 0.5181 & -0.0256 & & 0.6572 \\
\hline & & SD & 0.3191 & 0.0152 & 0.0039 & & 0.0192 \\
\hline \multirow{4}{*}{$\begin{array}{l}\text { Regression } \\
\text { formula } 9\end{array}$} & \multirow{4}{*}{$\begin{array}{c}\mathrm{X}_{1} \text { : Crown area } \\
\mathrm{X}_{2} \text { : Tree height } \\
\mathrm{X}_{3} \text { : Crown length }\end{array}$} & Average & 4.5598 & 0.2987 & 0.3397 & 0.0619 & 0.7296 \\
\hline & & Minimum & 4.3045 & 0.2501 & 0.2906 & 0.0515 & 0.7105 \\
\hline & & Maximum & 5.2995 & 0.3259 & 0.3679 & 0.0822 & 0.7465 \\
\hline & & $\mathrm{SD}$ & 0.2815 & 0.0188 & 0.0204 & 0.0081 & 0.0120 \\
\hline \multirow{4}{*}{$\begin{array}{l}\text { Regression } \\
\text { formula } 10\end{array}$} & \multirow{4}{*}{$\begin{array}{c}\mathrm{X}_{1}: \text { Crown area } \\
\mathrm{X}_{2}: \text { Tree height } \\
\mathrm{X}_{3}: \text { Crown length ratio }\end{array}$} & Average & 3.4295 & 0.2978 & 0.4024 & 0.0623 & 0.7301 \\
\hline & & Minimum & 3.1015 & 0.2497 & 0.3434 & 0.0521 & 0.7111 \\
\hline & & Maximum & 4.1671 & 0.3246 & 0.4502 & 0.0821 & 0.7469 \\
\hline & & SD & 0.2973 & 0.0186 & 0.0271 & 0.0080 & 0.0120 \\
\hline
\end{tabular}


Table 4. Results of regression analysis for estimating DBH (Japanese cypress).

\begin{tabular}{|c|c|c|c|c|c|c|c|}
\hline & Explanatory variable & & $\alpha$ & $\beta 1$ & $\beta 2$ & $\beta 3$ & Adjusted $\mathrm{R}^{2}$ \\
\hline \multirow{4}{*}{$\begin{array}{l}\text { Regression } \\
\text { formula } 1\end{array}$} & \multirow{4}{*}{$\mathrm{X}_{1}$ : Crown area } & Average & 6.6312 & 0.5834 & & & 0.5719 \\
\hline & & Minimum & 6.3783 & 0.5605 & & & 0.5206 \\
\hline & & Maximum & 6.9403 & 0.6007 & & & 0.6060 \\
\hline & & $\mathrm{SD}$ & 0.1721 & 0.0119 & & & 0.0221 \\
\hline \multirow{4}{*}{$\begin{array}{c}\text { Regression } \\
\text { formula } 2\end{array}$} & \multirow{4}{*}{$\mathrm{X}_{1}$ : Crown surface area } & Average & 10.4153 & 0.2534 & & & 0.3528 \\
\hline & & Minimum & 10.0644 & 0.2356 & & & 0.2967 \\
\hline & & Maximum & 10.9553 & 0.2669 & & & 0.3854 \\
\hline & & SD & 0.2553 & 0.0084 & & & 0.0231 \\
\hline \multirow{4}{*}{$\begin{array}{l}\text { Regression } \\
\text { formula } 3\end{array}$} & \multirow{4}{*}{$\mathrm{X}_{1}$ : Crown volume } & Average & 14.0008 & 0.1964 & & & 0.3899 \\
\hline & & Minimum & 13.8079 & 0.1851 & & & 0.3346 \\
\hline & & Maximum & 14.3428 & 0.2030 & & & 0.4204 \\
\hline & & SD & 0.1747 & 0.0051 & & & 0.0221 \\
\hline \multirow{4}{*}{$\begin{array}{c}\text { Regression } \\
\text { formula } 4\end{array}$} & \multirow{4}{*}{$\begin{array}{l}\mathrm{X}_{1}: \text { Crown area } \\
\mathrm{X}_{2} \text { : Tree height }\end{array}$} & Average & 3.1333 & 0.3357 & 0.4583 & & 0.7428 \\
\hline & & Minimum & 2.9819 & 0.3145 & 0.4321 & & 0.7154 \\
\hline & & Maximum & 3.2636 & 0.3582 & 0.4747 & & 0.7611 \\
\hline & & SD & 0.0866 & 0.0138 & 0.0124 & & 0.0160 \\
\hline \multirow{4}{*}{$\begin{array}{l}\text { Regression } \\
\text { formula } 5\end{array}$} & \multirow{4}{*}{$\begin{array}{c}\mathrm{X}_{1} \text { : Crown surface area } \\
\mathrm{X}_{2} \text { : Tree height }\end{array}$} & Average & 2.9530 & 0.1450 & 0.5761 & & 0.7236 \\
\hline & & Minimum & 2.8141 & 0.1354 & 0.5579 & & 0.6981 \\
\hline & & Maximum & 3.0678 & 0.1536 & 0.5922 & & 0.7440 \\
\hline & & SD & 0.0891 & 0.0064 & 0.0101 & & 0.0147 \\
\hline \multirow{4}{*}{$\begin{array}{l}\text { Regression } \\
\text { formula } 6\end{array}$} & \multirow{4}{*}{$\begin{array}{l}\mathrm{X}_{1}: \text { Crown volume } \\
\mathrm{X}_{2} \text { : Tree height }\end{array}$} & Average & 3.6518 & 0.1121 & 0.5606 & & 0.7301 \\
\hline & & Minimum & 3.5121 & 0.1053 & 0.5427 & & 0.7040 \\
\hline & & Maximum & 3.8132 & 0.1195 & 0.5770 & & 0.7524 \\
\hline & & SD & 0.1041 & 0.0046 & 0.0102 & & 0.0151 \\
\hline \multirow{4}{*}{$\begin{array}{l}\text { Regression } \\
\text { formula } 7\end{array}$} & \multirow{4}{*}{$\begin{array}{c}\mathrm{X}_{1}: \text { Crown area } \\
\mathrm{X}_{2}: \text { Crown length }\end{array}$} & Average & 6.0423 & 0.6694 & -0.0746 & & 0.5805 \\
\hline & & Minimum & 5.7933 & 0.6460 & -0.0944 & & 0.5317 \\
\hline & & Maximum & 6.3018 & 0.6922 & -0.0569 & & 0.6101 \\
\hline & & SD & 0.1597 & 0.0158 & 0.0115 & & 0.0217 \\
\hline \multirow{4}{*}{$\begin{array}{c}\text { Regression } \\
\text { formula } 8\end{array}$} & \multirow{4}{*}{$\begin{array}{c}\mathrm{X}_{1}: \text { Crown area } \\
\mathrm{X}_{2}: \text { Crown length ratio }\end{array}$} & Average & 8.3255 & 0.6655 & -0.1330 & & 0.6399 \\
\hline & & Minimum & 7.9146 & 0.6451 & -0.1490 & & 0.6005 \\
\hline & & Maximum & 8.8529 & 0.6791 & -0.1162 & & 0.6598 \\
\hline & & SD & 0.3106 & 0.0099 & 0.0094 & & 0.0197 \\
\hline \multirow{4}{*}{$\begin{array}{c}\text { Regression } \\
\text { formula } 9\end{array}$} & \multirow{4}{*}{$\begin{array}{c}\mathrm{X}_{1}: \text { Crown area } \\
\mathrm{X}_{2}: \text { Tree height } \\
\mathrm{X}_{3}: \text { Crown length }{ }^{*}\end{array}$} & Average & 3.1638 & 0.2829 & 0.4798 & 0.0354 & 0.7431 \\
\hline & & Minimum & 3.0087 & 0.2508 & 0.4576 & 0.0129 & 0.7153 \\
\hline & & Maximum & 3.3055 & 0.3174 & 0.4957 & 0.0453 & 0.7622 \\
\hline & & SD & 0.0914 & 0.0175 & 0.0121 & 0.0094 & 0.0161 \\
\hline \multirow{4}{*}{$\begin{array}{l}\text { Regression } \\
\text { formula } 10\end{array}$} & \multirow{4}{*}{$\begin{array}{c}\mathrm{X}_{1}: \text { Crown area } \\
\mathrm{X}_{2}: \text { Tree height } \\
\mathrm{X}_{3}: \text { Crown length ratio* }\end{array}$} & Average & 2.6764 & 0.2809 & 0.5171 & 0.0367 & 0.7433 \\
\hline & & Minimum & 2.4865 & 0.2476 & 0.4732 & 0.0146 & 0.7156 \\
\hline & & Maximum & 3.0199 & 0.3149 & 0.5352 & 0.0472 & 0.7626 \\
\hline & & SD & 0.1327 & 0.0177 & 0.0171 & 0.0093 & 0.0160 \\
\hline
\end{tabular}


$\mathrm{p}$-value of the power of crown length, $\beta 2$, was greater than 0.05 for both tree species. Compared to regression formula 1 , the coefficient of determination did not improve in regression formula 8 , where crown length ratio was added to crown area for Japanese cedar, while the p-value of the power of crown length, $\beta 2$, was greater than 0.05 . However, the coefficient of determination did improve for Japanese cypress, albeit not as much as when tree height was added. In regression formulae 9 and 10, where crown length and crown length ratio were added to crown area and tree height (regression formula 4), respectively, the coefficient of determination improved compared to regression formula 4 for both Japanese cedar and Japanese cypress; however, the p-value of the power of crown length or crown length ratio, $\beta 3$, exceeded 0.05 .

Regression formula Equations (1)-(6) and (9)-(10) for Japanese cedar, and Equation (10) had p-values less than 0.05 across all evaluations in a ten-fold cross validation; these equations utilized a combination of crown area, tree height, and crown length ratio also yielded the highest coefficients of determination. The p-values were less than 0.05 across all evaluations for regression formulae $1-6$ and 8 for Japanese cypress and Equation (4), which utilized crown area and tree height; these yielded the highest coefficients of determination.

The adjusted $R^{2}$ can be calculated using the following equation:

$$
\text { adjusted } R^{2}=1-\frac{n}{n-p}\left(1-R^{2}\right)
$$

Here, $n$ is the sample size, $p$ is the number of explanatory variables, and $R^{2}$ is the coefficient of determination.

Table 5 and Table 6 show the results comparing field survey values and DBH estimates using ten-fold cross validation. Out of the ten groups, the average, minimum and maximum values were calculated for the group used for validation and compared with the field survey results; the average error (difference in absolute value from the field survey was subtracted and averaged), correlation coefficient R, and RMSE were also calculated. The average, minimum and maximum values of average, minimum, maximum, average error, correlation coefficient and RMSE of ten-fold cross validation are shown in the tables. Regression formula 10, which used crown area, tree height, and crown length ratio as explanatory variables yielded the highest coefficient of determination with respect to DBH estimates for Japanese cedar; however, the minimum, maximum and average DBH values obtained from ten-fold cross validation were similar to values obtained using regression formula 9. The average error, correlation coefficient, and RMSE were also nearly identical to results obtained from regression formula 9, where the average of average errors was $7.3 \%$, the average of the correlation coefficients was 0.877 , and the average of the RMSEs was approximately $2.40 \mathrm{~cm}$.

However, regression formula 4 using crown area and tree height as explanatory variables yielded the highest coefficient of determination with respect to DBH estimates for Japanese cypress; nonetheless, a comparison with regression 
Table 5. Ten-fold cross validation of DBH estimates for Japanese cedar.

\begin{tabular}{|c|c|c|c|c|c|c|c|}
\hline & & $\begin{array}{c}\text { Average DBH } \\
(\mathrm{cm})\end{array}$ & $\begin{array}{l}\text { Minimum } \\
\text { DBH }\end{array}$ & $\begin{array}{l}\text { Maximum } \\
\text { DBH }\end{array}$ & $\begin{array}{l}\text { Average } \\
\text { error }\end{array}$ & $\mathrm{R}$ & RMSE \\
\hline \multirow{3}{*}{ Field data } & Average & 25.8 & 18.6 & 34.3 & & & \\
\hline & Minimum & 24.6 & 13.0 & 30.0 & & & \\
\hline & Maximum & 27.3 & 22.0 & 39.0 & & & \\
\hline \multirow{3}{*}{$\begin{array}{l}\text { Regression } \\
\text { formula } 1\end{array}$} & Average & 24.8 & 19.8 & 32.3 & $8.73 \%$ & 0.825 & 2.731 \\
\hline & Minimum & 23.6 & 15.8 & 27.3 & $6.10 \%$ & 0.633 & 1.760 \\
\hline & Maximum & 26.1 & 22.2 & 40.7 & $11.37 \%$ & 0.942 & 3.805 \\
\hline \multirow{3}{*}{$\begin{array}{l}\text { Regression } \\
\text { formula } 2\end{array}$} & Average & 24.5 & 20.7 & 30.3 & $10.83 \%$ & 0.656 & 3.357 \\
\hline & Minimum & 23.6 & 18.0 & 27.6 & $8.54 \%$ & 0.129 & 2.632 \\
\hline & Maximum & 25.3 & 22.0 & 34.0 & $13.31 \%$ & 0.898 & 4.377 \\
\hline \multirow{3}{*}{$\begin{array}{l}\text { Regression } \\
\text { formula } 3\end{array}$} & Average & 23.9 & 19.9 & 30.2 & $11.25 \%$ & 0.697 & 3.489 \\
\hline & Minimum & 22.9 & 16.7 & 26.8 & $9.12 \%$ & 0.215 & 2.421 \\
\hline & Maximum & 24.7 & 21.4 & 34.0 & $13.67 \%$ & 0.908 & 4.593 \\
\hline \multirow{3}{*}{$\begin{array}{l}\text { Regression } \\
\text { formula } 4\end{array}$} & Average & 24.9 & 18.9 & 31.8 & $7.37 \%$ & 0.870 & 2.420 \\
\hline & Minimum & 23.8 & 15.1 & 28.5 & $5.59 \%$ & 0.786 & 1.659 \\
\hline & Maximum & 25.9 & 21.8 & 36.5 & $9.51 \%$ & 0.953 & 3.740 \\
\hline \multirow{3}{*}{$\begin{array}{l}\text { Regression } \\
\text { formula } 5\end{array}$} & Average & 24.7 & 19.2 & 31.1 & $7.82 \%$ & 0.842 & 2.631 \\
\hline & Minimum & 23.7 & 15.4 & 28.2 & $5.19 \%$ & 0.689 & 1.854 \\
\hline & Maximum & 25.8 & 21.4 & 33.5 & $10.30 \%$ & 0.955 & 3.967 \\
\hline \multirow{3}{*}{$\begin{array}{l}\text { Regression } \\
\text { formula } 6\end{array}$} & Average & 24.2 & 18.8 & 30.6 & $8.30 \%$ & 0.855 & 2.779 \\
\hline & Minimum & 23.3 & 14.8 & 27.4 & $5.57 \%$ & 0.707 & 2.034 \\
\hline & Maximum & 25.2 & 21.1 & 32.7 & $11.70 \%$ & 0.961 & 4.146 \\
\hline \multirow{3}{*}{$\begin{array}{l}\text { Regression } \\
\text { formula } 7\end{array}$} & Average & 24.8 & 19.9 & 32.3 & $8.84 \%$ & 0.822 & 2.753 \\
\hline & Minimum & 23.5 & 15.8 & 27.3 & $6.22 \%$ & 0.616 & 1.780 \\
\hline & Maximum & 26.0 & 22.1 & 40.6 & $11.43 \%$ & 0.940 & 3.811 \\
\hline \multirow{3}{*}{$\begin{array}{l}\text { Regression } \\
\text { formula } 8\end{array}$} & Average & 24.8 & 19.8 & 32.1 & $8.59 \%$ & 0.831 & 2.696 \\
\hline & Minimum & 23.6 & 15.9 & 27.4 & $5.68 \%$ & 0.673 & 1.720 \\
\hline & Maximum & 26.3 & 22.2 & 40.5 & $11.90 \%$ & 0.947 & 3.791 \\
\hline \multirow{3}{*}{$\begin{array}{l}\text { Regression } \\
\text { formula } 9\end{array}$} & Average & 24.8 & 18.9 & 31.8 & $7.32 \%$ & 0.877 & 2.402 \\
\hline & Minimum & 23.8 & 14.8 & 28.2 & $5.53 \%$ & 0.776 & 1.651 \\
\hline & Maximum & 25.5 & 21.6 & 35.5 & $9.32 \%$ & 0.948 & 3.659 \\
\hline \multirow{3}{*}{$\begin{array}{l}\text { Regression } \\
\text { formula } 10\end{array}$} & Average & 24.8 & 18.9 & 31.8 & $7.31 \%$ & 0.877 & 2.404 \\
\hline & Minimum & 23.7 & 14.8 & 28.1 & $5.52 \%$ & 0.776 & 1.636 \\
\hline & Maximum & 25.5 & 21.6 & 35.5 & $9.14 \%$ & 0.948 & 3.702 \\
\hline
\end{tabular}

formulae $1-6$ and 8 , where the p-value is less than $5 \%$, showed that the ten-fold cross validation obtained from Equation (4) was the best result; the average of the average errors was $8.44 \%$, average of the correlation coefficients was 0.866 , and RMSE was $2.428 \mathrm{~cm}$. 
Table 6. Ten-fold cross validation of DBH estimates for Japanese cypress.

\begin{tabular}{|c|c|c|c|c|c|c|c|}
\hline & & $\begin{array}{c}\text { Average } \\
\text { DBH }(\mathrm{cm})\end{array}$ & $\begin{array}{c}\text { Minimum } \\
\text { DBH }\end{array}$ & $\begin{array}{c}\text { Maximum } \\
\text { DBH }\end{array}$ & $\begin{array}{l}\text { Average } \\
\text { error }\end{array}$ & $\mathrm{R}$ & RMSE \\
\hline \multirow{3}{*}{ Field data } & Average & 22.0 & 14.2 & 30.6 & & & \\
\hline & Minimum & 20.2 & 12.0 & 24.0 & & & \\
\hline & Maximum & 23.5 & 16.0 & 37.0 & & & \\
\hline \multirow{3}{*}{$\begin{array}{l}\text { Regression } \\
\text { formula } 1\end{array}$} & Average & 21.0 & 15.1 & 28.1 & $9.19 \%$ & 0.856 & 2.554 \\
\hline & Minimum & 19.6 & 12.4 & 23.8 & $6.28 \%$ & 0.765 & 1.660 \\
\hline & Maximum & 22.1 & 17.9 & 32.0 & $11.92 \%$ & 0.977 & 3.392 \\
\hline \multirow{3}{*}{$\begin{array}{l}\text { Regression } \\
\text { formula } 2\end{array}$} & Average & 20.6 & 17.6 & 26.3 & $13.85 \%$ & 0.581 & 3.848 \\
\hline & Minimum & 19.7 & 15.9 & 21.6 & $10.72 \%$ & 0.097 & 3.001 \\
\hline & Maximum & 22.2 & 18.6 & 33.5 & $16.50 \%$ & 0.896 & 4.927 \\
\hline \multirow{3}{*}{$\begin{array}{l}\text { Regression } \\
\text { formula } 3\end{array}$} & Average & 20.0 & 16.7 & 25.7 & $14.53 \%$ & 0.601 & 4.004 \\
\hline & Minimum & 19.0 & 14.8 & 21.1 & $10.50 \%$ & 0.131 & 2.987 \\
\hline & Maximum & 21.5 & 17.9 & 32.4 & $17.81 \%$ & 0.902 & 5.163 \\
\hline \multirow{3}{*}{$\begin{array}{l}\text { Regression } \\
\text { formula } 4\end{array}$} & Average & 21.1 & 14.6 & 28.1 & $8.44 \%$ & 0.866 & 2.428 \\
\hline & Minimum & 20.0 & 12.4 & 23.3 & $3.74 \%$ & 0.765 & 0.979 \\
\hline & Maximum & 22.1 & 17.9 & 32.0 & $11.92 \%$ & 0.973 & 3.392 \\
\hline \multirow{3}{*}{$\begin{array}{l}\text { Regression } \\
\text { formula } 5\end{array}$} & Average & 21.1 & 14.6 & 27.6 & $8.77 \%$ & 0.860 & 2.509 \\
\hline & Minimum & 20.3 & 12.4 & 23.9 & $5.44 \%$ & 0.767 & 1.285 \\
\hline & Maximum & 22.1 & 17.3 & 32.8 & $12.45 \%$ & 0.946 & 3.550 \\
\hline \multirow{3}{*}{$\begin{array}{l}\text { Regression } \\
\text { formula } 6\end{array}$} & Average & 20.8 & 14.4 & 27.2 & $9.01 \%$ & 0.864 & 2.602 \\
\hline & Minimum & 20.0 & 12.0 & 23.0 & $5.12 \%$ & 0.766 & 1.206 \\
\hline & Maximum & 21.7 & 17.1 & 32.2 & $13.12 \%$ & 0.957 & 3.653 \\
\hline \multirow{3}{*}{$\begin{array}{l}\text { Regression } \\
\text { formula } 7\end{array}$} & Average & 21.1 & 16.1 & 28.0 & $10.89 \%$ & 0.755 & 3.026 \\
\hline & Minimum & 19.6 & 14.5 & 23.7 & $6.06 \%$ & 0.460 & 1.972 \\
\hline & Maximum & 22.3 & 18.3 & 32.6 & $13.97 \%$ & 0.977 & 3.954 \\
\hline \multirow{3}{*}{$\begin{array}{l}\text { Regression } \\
\text { formula } 8\end{array}$} & Average & 21.1 & 15.7 & 28.3 & $9.91 \%$ & 0.798 & 2.821 \\
\hline & Minimum & 19.6 & 13.9 & 23.5 & $6.53 \%$ & 0.599 & 1.634 \\
\hline & Maximum & 22.3 & 18.7 & 31.5 & $13.04 \%$ & 0.961 & 3.647 \\
\hline \multirow{3}{*}{$\begin{array}{l}\text { Regression } \\
\text { formula } 9\end{array}$} & Average & 21.1 & 14.6 & 28.0 & $8.41 \%$ & 0.867 & 2.424 \\
\hline & Minimum & 20.1 & 12.4 & 23.3 & $3.95 \%$ & 0.765 & 0.960 \\
\hline & Maximum & 22.1 & 17.8 & 32.5 & $11.94 \%$ & 0.975 & 3.396 \\
\hline \multirow{3}{*}{$\begin{array}{l}\text { Regression } \\
\text { formula } 10\end{array}$} & Average & 21.1 & 14.6 & 28.0 & $8.40 \%$ & 0.867 & 2.420 \\
\hline & Minimum & 20.1 & 12.4 & 23.3 & $3.97 \%$ & 0.766 & 0.963 \\
\hline & Maximum & 22.1 & 17.8 & 32.5 & $11.99 \%$ & 0.975 & 3.404 \\
\hline
\end{tabular}

The average DBH was $24.8 \mathrm{~cm}$ for Japanese cedar, which was $1 \mathrm{~cm}$ smaller compared to $25.8 \mathrm{~cm}$ in a field survey, while the average DBH was $21.1 \mathrm{~cm}$ for Japanese cypress, $0.9 \mathrm{~cm}$ smaller compared to $22.0 \mathrm{~cm}$ in a field survey. These results showed that DBHs were calculated as slightly smaller than the actual results for both species. 
Equations (8) and (9) are the resulting DBH regression formulae using the average value of the coefficient obtained from ten-fold cross validation of regression formula 10 (Japanese cedar) and regression formula 4 (Japanese cypress) where the coefficients of determination were the highest. Both are used to estimate the stem volume of an individual tree as an average coefficient regression formula.

$$
\begin{gathered}
D B H s=3.430 \times C a^{0.298} \times h^{0.402} \times C r^{0.062} \\
D B H h=3.133 \times C a^{0.336} \times h^{0.458}
\end{gathered}
$$

where DBHs is the DBH of a Japanese cedar $(\mathrm{cm})$ and DBHh is the DBH of Japanese cypress $(\mathrm{cm})$.

Using the average coefficient regression formulae (Equations (8) and (9)), DBH was calculated at an individual tree level. The average DBH was calculated for the survey plot, and the correlation coefficient, average error, and RMSE obtained from a comparison of the minimum, maximum, average, and standard deviation of the average DBH per plot and calculated field survey, as shown in Table 7. The average DBH from the field survey and LiDAR analysis are compared graphically in Figure 5. The average DBH was $25.8 \mathrm{~cm}$ in the field survey and $24.8 \mathrm{~cm}$ from LiDAR analysis of Japanese cedar, while the average DBH was $22.0 \mathrm{~cm}$ in the field survey and $21.1 \mathrm{~cm}$ from LiDAR analysis of Japanese cypress. Both LiDAR results were underestimated compared to similar field surveys results obtained. The correlation coefficient was 0.86 for both cedar and cypress, the average error was $6.9 \%$ and $8.3 \%$ and RMSE was $2.38 \mathrm{~cm}$ and 2.51 $\mathrm{cm}$ for cedar and cypress, respectively, showing the high degree of accuracy of DBH estimates. However, the maximum average DBH obtained by LiDAR analysis was $4.2 \mathrm{~cm}$ for Japanese cedar and $5 \mathrm{~cm}$ for Japanese cypress, which was smaller compared to the field survey. Figure 5 shows that the coefficient of approximation obtained from the scatter plot was 1.0174 and 1.0498 for Japanese cedar and Japanese cypress, and the DBH obtained from LiDAR analyses were nearly identical compared to field survey results. As shown, there is also a high degree of correlation in the estimate results.

Table 7. Results of DBH estimates using the average coefficient regression formula.

\begin{tabular}{ccccc}
\hline & \multicolumn{3}{c}{ Japanese Cedar } & \multicolumn{2}{c}{ Japanese Cypress } \\
\cline { 2 - 5 } & Field data & LiDAR data & Field data & LiDAR data \\
\hline AverageDBH & 25.8 & 24.8 & 22.0 & 21.1 \\
Minimum & 13.0 & 15.1 & 12.0 & 12.6 \\
Maximum & 39.0 & 34.8 & 37.0 & 3.0 \\
SD & 4.3 & 3.6 & & 3.8 \\
R & & 0.86 & 0.86 \\
Average error & & $6.9 \%$ & & $8.3 \%$ \\
RMSE & & 2.38 & & 2.51 \\
\hline
\end{tabular}




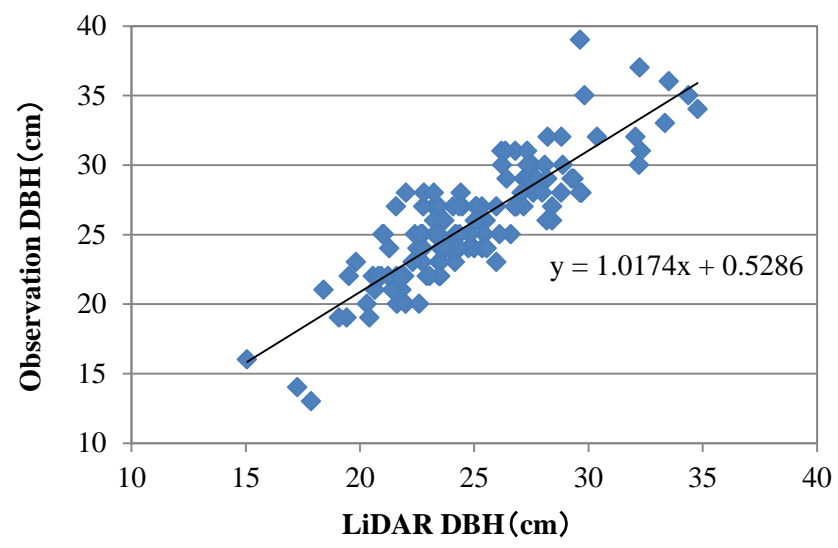

(a)

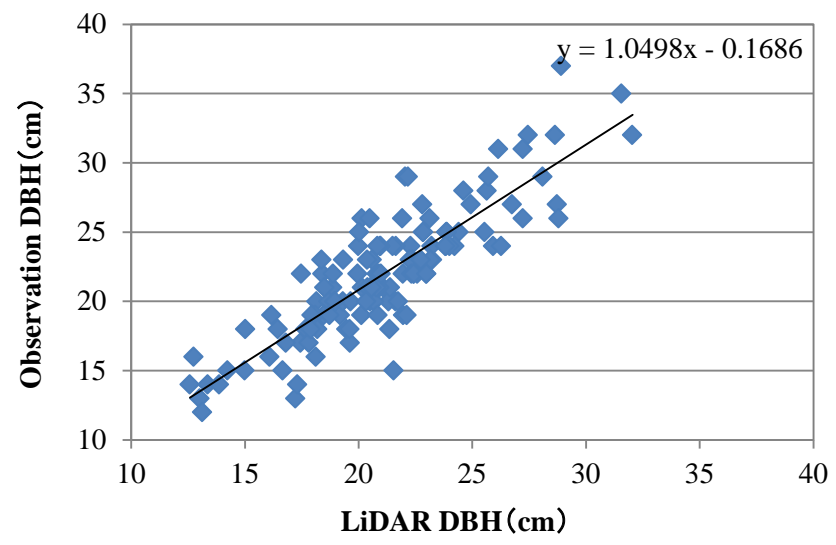

(b)

Figure 5. DBH calculated using the average coefficient regression formula (left: Japanese cedar, right: Japanese cypress).

The minimum DBH was $4.2-5 \mathrm{~cm}$ smaller in the LiDAR analysis; however, because the average coefficient regression formula used the average $\mathrm{DBH}$ from field survey plots, this may have been influenced by the narrowing range in $\mathrm{DBH}$ compared to individual DBH size obtained from field surveys. For this reason, two DBH histograms, one from the field survey and the other calculated using the average coefficient regression formula (Figure 6 and Figure 7). The figures show that tree height distribution was nearly equal in the field survey and LiDAR analysis; however, many DBH values were smaller where large DBHs were underestimated, compared to values obtained from the field survey.

\subsection{Individual Stem Volume Estimates}

Table 8 and Table 9 show the average individual stem volumes in the surveyed plots calculated using the DBH volume equation. This equation was based on the individual tree height measured by LiDAR analysis and regression formulae obtained from ten-fold cross validation.

The average single tree volume, minimum volume, maximum volume, correlation coefficient R, RMSE, and average error, which is calculated by dividing the difference (absolute value) of the field survey by the results of the field survey and calculating the mean, were calculated from the verification group, as shown in Table 5 and Table 6.

While regression formula 10 resulted in the highest coefficient of determination in estimating DBH for Japanese cedar, equations 4 , 9, and 10 were nearly equal in value upon comparing the calculation results of the average individual stem volumes. The average individual stem volume based on regression formula 10 was $0.48 \mathrm{~m}^{3}$ for Japanese cedar, $0.05 \mathrm{~m}^{3}$ smaller than the $0.53 \mathrm{~m}^{3}$ obtained from the field survey. The range in values between the field survey and LiDAR analysis was $0.10 \mathrm{~m}^{3}-1.20 \mathrm{~m}^{3}$ for the former and $0.11 \mathrm{~m}^{3}-1.12 \mathrm{~m}^{3}$ for the latter, revealing that the average individual stem volume had the same calculated range. The average error for regression formula 10 was $14.91 \%$, the correlation coefficient was 0.905 , and RMSE was 0.102 . However, regression formula 4 yielded the 


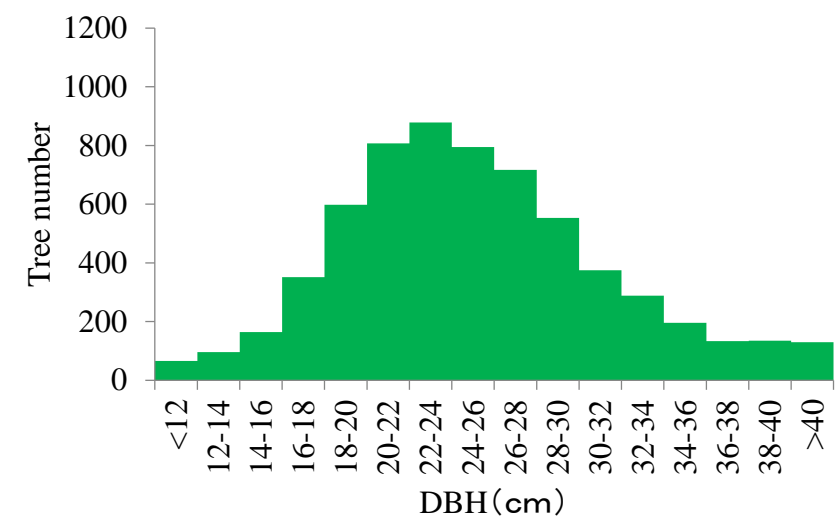

(a)

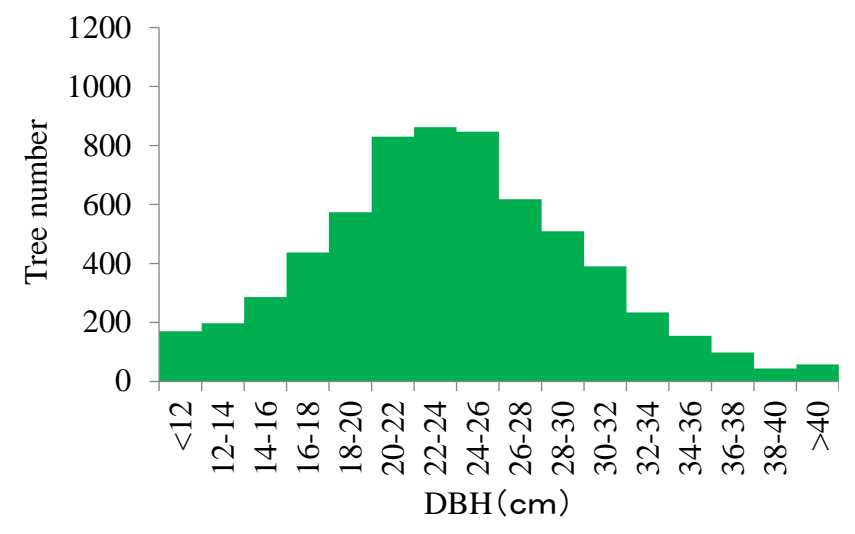

(b)

Figure 6. DBH histograms for tree observations and LiDAR measurements (Japanese cedar, left: observation, right: LiDAR).

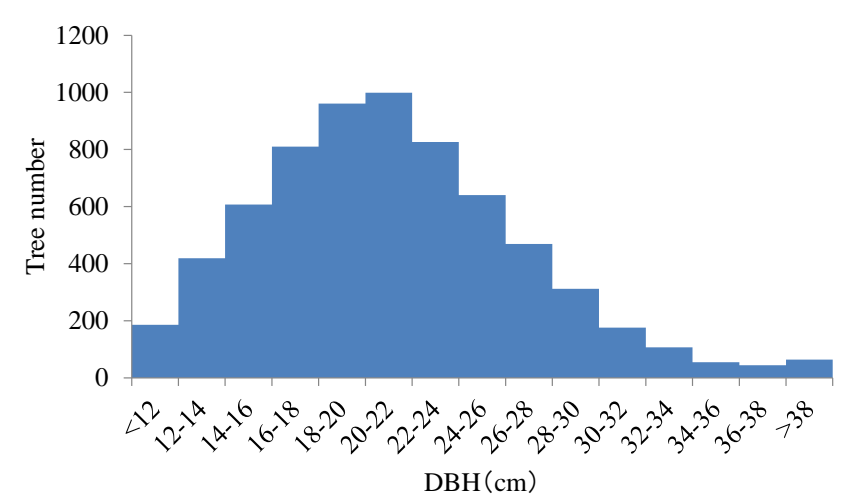

(a)

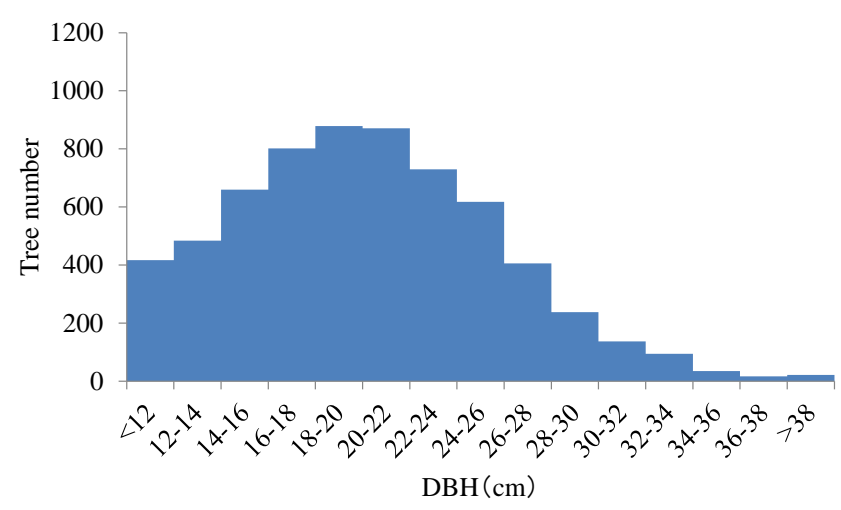

(b)

Figure 7. DBH histograms for tree observations and LiDAR measurements (Japanese cypress, left: observation, right: LiDAR).

Highest coefficient of determination for Japanese cypress; when comparing equations $1-6$ and 8 , with p-values $<5 \%$, the average individual stem volume had the highest accuracy when the DBH obtained from regression formula 4 was used. The average individual stem volume for Japanese cedar was $0.31 \mathrm{~m}^{3}$, which was $0.05 \mathrm{~m}^{3}$ smaller than the $0.36 \mathrm{~m}^{3}$ obtained from the field survey. The range in values between the field survey and LiDAR analysis was $0.06 \mathrm{~m}^{3}-1.30 \mathrm{~m}^{3}$ for the former and $0.05 \mathrm{~m}^{3}-1.00 \mathrm{~m}^{3}$ for the latter, revealing that the high stem volume estimates decreased. The average error from equation 4 was $19.11 \%$, the correlation coefficient was 0.911 , and RMSE was 0.091 , where the average error was greater compared to Japanese cypress.

Table 10 shows the calculated minimum, maximum, mean, and standard deviation values for the average individual stem volume, which was calculated using DBH Equations (8) and (9) with trees included in the survey plot. In addition, the correlation coefficient, average error, and RMSE were calculated by comparing with results from the field survey. Compared to the field survey, the values were underestimated for both Japanese cedar and Japanese cypress, as was the case with the ten-fold cross validation, where the average value of the average individual stem volumes were $0.04 \mathrm{~m}^{3}$ and $0.05 \mathrm{~m}^{3}$ for cedar and cypress, 
Table 8. Ten-fold cross validation of stem volume estimates for Japanese cedar.

\begin{tabular}{|c|c|c|c|c|c|c|c|}
\hline & & $\begin{array}{l}\text { Average single } \\
\text { tree volume }\left(\mathrm{m}^{3}\right)\end{array}$ & $\begin{array}{l}\text { Minimum } \\
\text { volume }\end{array}$ & $\begin{array}{l}\text { Maximum } \\
\text { volume }\end{array}$ & $\begin{array}{l}\text { Average } \\
\text { error }\end{array}$ & $\mathrm{R}$ & RMSE \\
\hline \multirow{3}{*}{ Field data } & Average & 0.53 & 0.20 & 0.94 & & & \\
\hline & Minimum & 0.47 & 0.10 & 0.78 & & & \\
\hline & Maximum & 0.59 & 0.28 & 1.20 & & & \\
\hline \multirow{3}{*}{$\begin{array}{l}\text { Regression } \\
\text { formula } 1\end{array}$} & Average & 0.48 & 0.23 & 0.84 & $15.80 \%$ & 0.907 & 0.101 \\
\hline & Minimum & 0.43 & 0.13 & 0.68 & $9.53 \%$ & 0.842 & 0.056 \\
\hline & Maximum & 0.54 & 0.32 & 1.02 & $22.19 \%$ & 0.983 & 0.170 \\
\hline \multirow{3}{*}{$\begin{array}{l}\text { Regression } \\
\text { formula } 2\end{array}$} & Average & 0.45 & 0.25 & 0.74 & $18.80 \%$ & 0.879 & 0.128 \\
\hline & Minimum & 0.42 & 0.16 & 0.59 & $14.91 \%$ & 0.734 & 0.088 \\
\hline & Maximum & 0.50 & 0.32 & 0.87 & $23.83 \%$ & 0.967 & 0.198 \\
\hline \multirow{3}{*}{$\begin{array}{l}\text { Regression } \\
\text { formula } 3\end{array}$} & Average & 0.44 & 0.24 & 0.73 & $19.54 \%$ & 0.889 & 0.134 \\
\hline & Minimum & 0.40 & 0.14 & 0.57 & $15.77 \%$ & 0.765 & 0.087 \\
\hline & Maximum & 0.48 & 0.31 & 0.86 & $25.03 \%$ & 0.966 & 0.206 \\
\hline \multirow{3}{*}{$\begin{array}{l}\text { Regression } \\
\text { formula } 4\end{array}$} & Average & 0.49 & 0.20 & 0.88 & $14.89 \%$ & 0.901 & 0.103 \\
\hline & Minimum & 0.44 & 0.12 & 0.73 & $9.29 \%$ & 0.825 & 0.057 \\
\hline & Maximum & 0.53 & 0.27 & 1.13 & $19.83 \%$ & 0.965 & 0.173 \\
\hline \multirow{3}{*}{$\begin{array}{l}\text { Regression } \\
\text { formula } 5\end{array}$} & Average & 0.47 & 0.19 & 0.87 & $15.83 \%$ & 0.897 & 0.105 \\
\hline & Minimum & 0.43 & 0.12 & 0.68 & $12.64 \%$ & 0.813 & 0.086 \\
\hline & Maximum & 0.54 & 0.28 & 1.10 & $20.54 \%$ & 0.954 & 0.151 \\
\hline \multirow{3}{*}{$\begin{array}{l}\text { Regression } \\
\text { formula } 6\end{array}$} & Average & 0.46 & 0.19 & 0.84 & $17.18 \%$ & 0.892 & 0.118 \\
\hline & Minimum & 0.42 & 0.11 & 0.67 & $13.48 \%$ & 0.789 & 0.090 \\
\hline & Maximum & 0.52 & 0.27 & 1.06 & $22.45 \%$ & 0.964 & 0.193 \\
\hline \multirow{3}{*}{$\begin{array}{l}\text { Regression } \\
\text { formula } 7\end{array}$} & Average & 0.48 & 0.23 & 0.84 & $15.91 \%$ & 0.908 & 0.102 \\
\hline & Minimum & 0.43 & 0.13 & 0.67 & $9.79 \%$ & 0.842 & 0.052 \\
\hline & Maximum & 0.53 & 0.32 & 1.02 & $22.33 \%$ & 0.983 & 0.170 \\
\hline \multirow{3}{*}{$\begin{array}{l}\text { Regression } \\
\text { formula } 8\end{array}$} & Average & 0.49 & 0.22 & 0.85 & $15.87 \%$ & 0.902 & 0.102 \\
\hline & Minimum & 0.44 & 0.13 & 0.70 & $9.24 \%$ & 0.841 & 0.060 \\
\hline & Maximum & 0.54 & 0.31 & 1.04 & $22.24 \%$ & 0.980 & 0.169 \\
\hline \multirow{3}{*}{$\begin{array}{l}\text { Regression } \\
\text { formula } 9\end{array}$} & Average & 0.49 & 0.20 & 0.89 & $14.90 \%$ & 0.905 & 0.102 \\
\hline & Minimum & 0.44 & 0.11 & 0.71 & $9.46 \%$ & 0.825 & 0.054 \\
\hline & Maximum & 0.54 & 0.28 & 1.12 & $19.50 \%$ & 0.971 & 0.172 \\
\hline \multirow{3}{*}{$\begin{array}{l}\text { Regression } \\
\text { formula } 10\end{array}$} & Average & 0.48 & 0.20 & 0.88 & $14.91 \%$ & 0.905 & 0.102 \\
\hline & Minimum & 0.43 & 0.11 & 0.70 & $9.50 \%$ & 0.825 & 0.054 \\
\hline & Maximum & 0.54 & 0.28 & 1.12 & $19.81 \%$ & 0.971 & 0.174 \\
\hline
\end{tabular}

respectively, and the maximum values were $0.08 \mathrm{~m}^{3}$ and $0.29 \mathrm{~m}^{3}$, respectively. The average error for Japanese cypress was $18.9 \%$, which was greater than Japanese cedar; however, the correlation coefficient was 0.88 and 0.91 for cedar and cypress, respectively, and the RMSE was $0.10 \mathrm{~m}^{3}$ for both species. 
Table 9. Ten-fold cross validation of stem volume estimates for Japanese cypress.

\begin{tabular}{|c|c|c|c|c|c|c|c|}
\hline & & $\begin{array}{l}\text { Average single } \\
\text { tree volume }\left(\mathrm{m}^{3}\right)\end{array}$ & $\begin{array}{l}\text { Minimum } \\
\text { volume }\end{array}$ & $\begin{array}{l}\text { Maximum } \\
\text { volume }\end{array}$ & $\begin{array}{l}\text { Average } \\
\text { error }\end{array}$ & $\mathrm{R}$ & RMSE \\
\hline \multirow{3}{*}{ Field data } & Average & 0.36 & 0.09 & 0.82 & & & \\
\hline & Minimum & 0.31 & 0.06 & 0.46 & & & \\
\hline & Maximum & 0.43 & 0.15 & 1.30 & & & \\
\hline \multirow{3}{*}{$\begin{array}{l}\text { Regression } \\
\text { formula } 1\end{array}$} & Average & 0.31 & 0.10 & 0.67 & $19.23 \%$ & 0.917 & 0.090 \\
\hline & Minimum & 0.26 & 0.05 & 0.37 & $10.05 \%$ & 0.808 & 0.047 \\
\hline & Maximum & 0.36 & 0.16 & 1.00 & $27.89 \%$ & 0.977 & 0.160 \\
\hline \multirow{3}{*}{$\begin{array}{l}\text { Regression } \\
\text { formula } 2\end{array}$} & Average & 0.28 & 0.13 & 0.53 & $25.28 \%$ & 0.849 & 0.137 \\
\hline & Minimum & 0.25 & 0.09 & 0.34 & $19.88 \%$ & 0.684 & 0.070 \\
\hline & Maximum & 0.33 & 0.18 & 0.88 & $39.85 \%$ & 0.953 & 0.247 \\
\hline \multirow{3}{*}{$\begin{array}{l}\text { Regression } \\
\text { formula } 3\end{array}$} & Average & 0.27 & 0.12 & 0.51 & $26.34 \%$ & 0.855 & 0.144 \\
\hline & Minimum & 0.24 & 0.08 & 0.32 & $20.19 \%$ & 0.677 & 0.081 \\
\hline & Maximum & 0.31 & 0.17 & 0.83 & $41.72 \%$ & 0.959 & 0.251 \\
\hline \multirow{3}{*}{$\begin{array}{l}\text { Regression } \\
\text { formula } 4\end{array}$} & Average & 0.31 & 0.09 & 0.67 & $19.11 \%$ & 0.911 & 0.091 \\
\hline & Minimum & 0.27 & 0.05 & 0.40 & $10.05 \%$ & 0.808 & 0.047 \\
\hline & Maximum & 0.36 & 0.16 & 1.00 & $27.89 \%$ & 0.955 & 0.160 \\
\hline \multirow{3}{*}{$\begin{array}{l}\text { Regression } \\
\text { formula } 5\end{array}$} & Average & 0.31 & 0.09 & 0.65 & $19.98 \%$ & 0.903 & 0.097 \\
\hline & Minimum & 0.28 & 0.05 & 0.47 & $11.26 \%$ & 0.774 & 0.051 \\
\hline & Maximum & 0.36 & 0.15 & 0.94 & $29.68 \%$ & 0.958 & 0.176 \\
\hline \multirow{3}{*}{$\begin{array}{l}\text { Regression } \\
\text { formula } 6\end{array}$} & Average & 0.30 & 0.09 & 0.63 & $20.58 \%$ & 0.906 & 0.101 \\
\hline & Minimum & 0.27 & 0.04 & 0.44 & $11.89 \%$ & 0.778 & 0.054 \\
\hline & Maximum & 0.35 & 0.15 & 0.93 & $30.45 \%$ & 0.962 & 0.183 \\
\hline \multirow{3}{*}{$\begin{array}{l}\text { Regression } \\
\text { formula } 7\end{array}$} & Average & 0.32 & 0.12 & 0.66 & $20.21 \%$ & 0.886 & 0.100 \\
\hline & Minimum & 0.26 & 0.08 & 0.40 & $11.19 \%$ & 0.724 & 0.061 \\
\hline & Maximum & 0.37 & 0.20 & 0.91 & $32.57 \%$ & 0.974 & 0.178 \\
\hline \multirow{3}{*}{$\begin{array}{l}\text { Regression } \\
\text { formula } 8\end{array}$} & Average & 0.32 & 0.11 & 0.68 & $19.84 \%$ & 0.892 & 0.096 \\
\hline & Minimum & 0.27 & 0.06 & 0.42 & $12.29 \%$ & 0.777 & 0.061 \\
\hline & Maximum & 0.37 & 0.19 & 0.97 & $29.00 \%$ & 0.957 & 0.161 \\
\hline \multirow{3}{*}{$\begin{array}{l}\text { Regression } \\
\text { formula } 9\end{array}$} & Average & 0.31 & 0.09 & 0.67 & $19.18 \%$ & 0.912 & 0.092 \\
\hline & Minimum & 0.27 & 0.05 & 0.41 & $9.81 \%$ & 0.800 & 0.046 \\
\hline & Maximum & 0.36 & 0.15 & 1.00 & $28.38 \%$ & 0.959 & 0.162 \\
\hline \multirow{3}{*}{$\begin{array}{l}\text { Regression } \\
\text { formula } 10\end{array}$} & Average & 0.31 & 0.09 & 0.67 & $19.16 \%$ & 0.912 & 0.092 \\
\hline & Minimum & 0.27 & 0.05 & 0.41 & $9.82 \%$ & 0.800 & 0.046 \\
\hline & Maximum & 0.36 & 0.15 & 0.99 & $28.28 \%$ & 0.960 & 0.162 \\
\hline
\end{tabular}

A graph comparing the average individual stem volumes for the field survey and LiDAR analysis is shown in Figure 8. The coefficient of approximation obtained from the scatter plot was 0.9438 for Japanese cedar and 1.1011 for Japanese cypress, which suggests that cypress tends to be underestimated. There is a high degree of correlation between the stem volume calculated using LiDAR analysis and the average individual stem volume from the field survey. 
Table 10. Stem volumes calculated using the DBH average coefficient regression formula.

\begin{tabular}{ccccc}
\hline & \multicolumn{3}{c}{ Japanese Cedar } & \multicolumn{2}{c}{ Japanese Cypress } \\
\cline { 2 - 5 } & Field data & LiDAR data & Field data & LiDAR data \\
\hline Average volume & 0.53 & 0.49 & 0.36 & 0.31 \\
Minimum & 0.10 & 0.11 & 0.06 & 0.05 \\
Maximum & 1.20 & 1.12 & 0.20 & 1.01 \\
SD & 0.20 & 0.19 & & 0.17 \\
R & & 0.88 & 0.91 \\
Average error & & $14.4 \%$ & & $18.9 \%$ \\
RMSE & & 0.10 & 0.10 \\
\hline
\end{tabular}

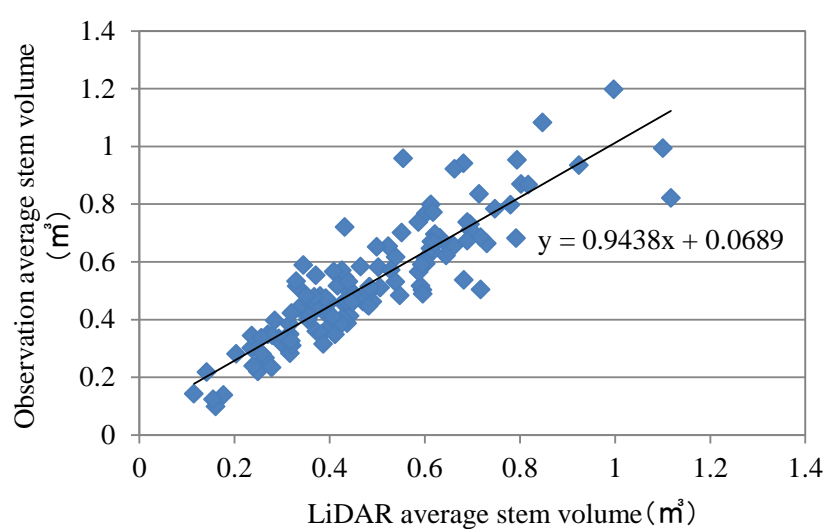

(a)

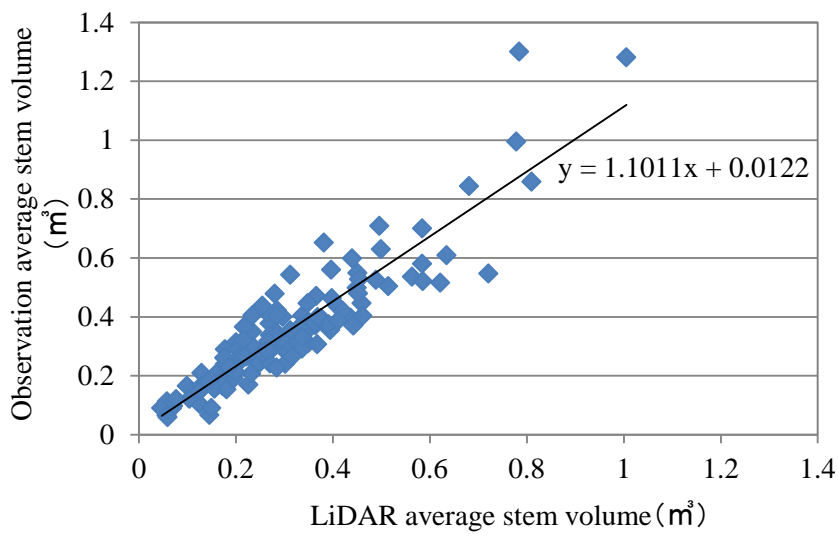

(b)

Figure 8. Average stem volume calculated using the average coefficient regression formula (left: Japanese cedar, right: Japanese cypress).

\section{Discussions and Conclusions}

To consider an alternative method to field surveys, this study utilized individual tree detection to establish a regression formula effective for estimating DBH using a ten-fold cross validation. Regression formulae to estimate $\mathrm{DBH}$ were tried with ten patterns of equations, using combinations of one to three explanatory variables. The stem volume for an individual tree was estimated from the obtained DBH and tree height, and the results were compared with those from a field survey.

While estimating $\mathrm{DBH}$, the coefficient of determination for the regression formula improved as the number of explanatory variables increased; the estimation accuracy also improved, especially after adding tree height. Compared to regression formulae that used crown area, the coefficient of determination was smaller for equations that used the crown surface area or crown volume due to the calculation methods for crown surface area and volume. This study assumed a conical shape for the crown shape to calculate the crown surface area and volume, which are likely to have been affected by differences in the actual crown surface area and volume values. In particular, the crown length shortens on the 
ridge side and lengthens on the valley side, and the error increased when calculating the crown surface area and crown volume. The p-value was not less than $5 \%$ for regression formulae 7 and 8 for Japanese cedar and formulae 7, 9, and 10 for Japanese cypress; their common feature was the p-values for crown length or crown length ratio was not less than $5 \%$. In addition, neither crown length nor crown length ratio had a significant contribution on the DBH estimates. Furthermore, there were no significant differences when comparing the coefficient of determination for regression formula 1 , where crown area alone was used as an explanatory variable, and formulae 7 and 8 , where crown length and crown length ratio were added to crown area, as shown in Table 3 and Table 4. However, the crown length and length ratio values may change by accurately measuring crown surface area and volume. Therefore, an accurate understanding of the shape of the tree crown and their contributions as explanatory variables are future challenges.

For explanatory variables to estimate DBH, the coefficient of determination was the highest for a combination crown area, tree height, and crown length ratio for Japanese cedar, and a combination of crown area and tree height for Japanese cypress. While there were differences in explanatory variables used for the cedar and cypress, crown length, maximum crown length, and standard deviation of the cedar shown on Table 1 were greater than the corresponding values for cypress by an average value of $0.4 \mathrm{~m}, 1.2 \mathrm{~m}$, and 0.3 , respectively, which were likely affected by large crown lengths and variations in values.

By comparing the field survey results with those obtained from the average coefficient regression formula equation, the RMSE was $2.38 \mathrm{~cm}$ and error rate was $9.2 \%$ for DBH of $13-39 \mathrm{~cm}$ (average DBH $25.8 \mathrm{~cm}$ ) plots for Japanese cedar, while the RMSE was $2.51 \mathrm{~cm}$ and error rate was $11.4 \%$ for DBH of $12-37$ $\mathrm{cm}$ (average DBH $22 \mathrm{~cm}$ ) plots for Japanese cypress. Compared to past studies where the error was $4.6 \mathrm{~cm}$ and error rate was $10 \%$ for DBH of $10-70 \mathrm{~cm}$ (Yao et al., 2012), or error of $13 \mathrm{~cm}$ and error rate of $17 \%$ for DBH of $28-84 \mathrm{~cm}$ (Verma et al., 2014), this study yielded error rates that were similar or slightly smaller, despite the differences in studied tree species and range in DBH values.

Because an average value of survey plots was used for objective variables and explanatory variables in regression analysis, the smallest DBH was greater than the value of an individual tree while the largest DBH decreased. Therefore, for the range in values applied to the regression formula for estimating $\mathrm{DBH}$, the accuracy estimates for the minimum and maximum DBH decreased. As shown in Figure 6 and Figure 7, the number of trees increased with smaller DBH value obtained through LiDAR analysis compared to the value obtained from the field survey, and the number decreased with larger DBH value.

While it was difficult to understand the position of every tree from the field survey, terrestrial laser-based measurement systems have made progress in recent years, and determining tree positions with a GIS has become easier. A challenge for the future is utilizing this technology, and applying a regression formula based on an airborne LiDAR analysis using the DBH of an individual tree 
rather than an average value of survey plots. Extending the range in DBH applicability should also be addressed in the future.

To calculate the average individual tree stem volume, regression for mulae with p-values $<5 \%$ were considered, and formulae 4,9 , and 10 yielded similar results for Japanese cedar. For Japanese cypress, regression formula 4 calculated the stem volume with the highest accuracy. In addition, a comparison of the average individual stem volume resulted in an average error of $14.4 \%$ for Japanese cedar and $18.9 \%$ for Japanese cypress. Because DBHs are generally calculated conservatively, the average individual stem volumes were also smaller by approximately $0.05 \mathrm{~m}^{3}$ for both tree species compared to the results obtained from the field survey. The error was greater for Japanese cypress compared to Japanese cedar potentially because of the crown shape. While an individual Japanese cedar has an independent crown, Japanese cypress crowns overlap with adjacent ones, which makes determining crown shape relatively more difficult, thereby affecting the estimation accuracy. The crown shape also affects the precision of individual tree detection, and given that the error for individual tree detection used in this study was $7.0 \%$ for Japanese cedar and $9.8 \%$ for Japanese cypress (Ogawa, Kira, Hikichi, Oono, \& Wachi, 2013), Japanese cypress is likely to have a greater margin of error when calculating the average stem volume. Therefore, improving the accuracy of individual tree detection is also an important problem for estimating individual stem volume.

Based on our study findings, we propose that the regression formula for estimating DBH can be applied across the entire Saga Prefecture in Japan, and determined crown area and tree height are effective explanatory variables for the regression formulae based on the results from $\mathrm{DBH}$ and stem volume estimations. Through airborne LiDAR analysis, the study also showed that the DBH can be estimated with an error of $<3 \mathrm{~cm}$ from a single regression formula for both Japanese cedar and Japanese cypress. Additionally, stem volume can likely be estimated with an accuracy of $<20 \%$ based on calculations of stem volume using the tree height and $\mathrm{DBH}$ of individual trees.

\section{Acknowledgements}

This study used data measurements and field survey results from the Saga Eastern District Airborne LiDAR Surveying Commission, Saga Western District Airborne LiDAR-Surveying Commission, and Saga Prefecture Forest Data Analysis Commission, provided by Saga Prefecture. We would like to express our sincere gratitude to the Saga Prefecture Forest Maintenance Division, which provided the data used in the study and forest registration information.

\section{References}

Bechtold, W. A. (2004). Largest-Crown-Width Prediction Models for 53 Species in the Western United States. Western Journal of Applied Forestry, 19, 245-251.

Forestry Agency (1970). Table of Standing Tree Trunk Volume: Western Japan Version. 
Tokyo: Japan Forestry Survey Group.

Hall, R., Morton, R., \& Nesby, R. (1989). A Comparison of Existing Models for DBH Estimation from Large-Scale Photos. The Forestry Chronicle, 65, 114-120. https://doi.org/10.5558/tfc65114-2

Hemery, G. E., Savill, P. S., \& Pryor, S. N. (2005). Applications of the Crown Diameter-Stem Diameter Relationship for Different Species of Broadleaved Trees. Forest Ecology and Management, 215, 285-294. https://doi.org/10.1016/j.foreco.2005.05.016

Heurich, M., Persson, A., Holmgren, J., \& Kennel, E. (2004). Detecting and Measuring Individual Trees with Laser Scanning in Mixed Mountain Forest of Central Europe using an Algorithm Developed for Swedish Boreal Forest Conditions. International Archives of Photogrammetry, Remote Sensing and Spatial Information Sciences, 36, 307-312.

Hyyppä, J., Mielonen, T., Hyyppä, H., Maltamo, M., Yu, X., Honkavaara, E., \& Kaartinen, H. (2005). Using Individual Tree Crown Approach for Forest Volume Extraction with Aerial Images and Laser Point Clouds. The International Archives of the Photogrammetry, Remote Sensing and Spatial Information Sciences, 36, W19.

Hyyppa, J. (2001). A Segmentation-Based Method to Retrieve Stem Volume Estimates from 3-D Tree Height Models Produced by Laser Scanners. IEEE Transactions on Geoscience and Remote Sensing, 39, 969-975. https://doi.org/10.1109/36.921414

Ketterings, Q. M., Coe, R., van Noordwijk, M., Ambagau', Y., \& Palm, C. A. (2001). Reducing Uncertainty in the Use of Allometric Biomass Equations for Predicting Above-Ground Tree Biomass in Mixed Secondary Forests. Forest Ecology and Management, 146, 199-209. https://doi.org/10.1016/S0378-1127(00)00460-6

Nakajima, I. (1973). A Study of Forest Survey Methods Utilizing Aerial Photographs. Bulletin of the Government Forest Experiment Station, 251, 1-253.

Nielsen, U., Aldred, A., \& MacLeod, D. (1979). A Forest Inventory in the Yukon using Large Scale Photo Sampling Techniques. Information Report, No. FMR-X-121, Forest Management Institute (Canada).

Ogawa, K., Kira, T., Hikichi, A., Oono, K., \& Wachi, A. (2013). Efforts on Forest Zoning in Saga Prefecture Utilizing Forest Laser Analysis Data. Paper Presented at the Japanese Forest Society Conference Presentation Database 124th Conference of the Japanese Forest.

Oono, K., Numata, Y., \& Hirano, A. (2008). An Improved Method of Individual Tree Detection using Airborne LiDAR.

Persson, Å., Holmgrem, J., \& Söderman, U. (2002). Detecting and Measuring Individual Trees using an Airborne Laser Scanner. Photogrammetric Engineering \& Remote Sensing, 68, 925-932.

Popescu, S. C., Wynne, R. H., \& Nelson, R. F. (2002). Estimating Plot-Level Tree Heights with Lidar: Local Filtering with a Canopy-Height Based Variable Window Size. Computers and Electronics in Agriculture, 37, 71-95.

https://doi.org/10.1016/S0168-1699(02)00121-7

Soille, P. (2013). Morphological Image Analysis: Principles and Applications. Berlin: Springer Science \& Business Media.

Takahashi, T., Awaya, Y., Hirata, Y., Furuya, N., Sakai, T., \& Sakai, A. (2008). Estimation of Stand Volume by Fusing Low Laser-Sampling Density LiDAR Data with QuickBird Panchromatic Imagery in Closed-Canopy Japanese Cedar (Cryptomeria japonica) Plantations. In 8th International Conference on LiDAR Applications in Forest Assessment and Inventory (86-94). Edinburgh: Heriot-Watt University. 
Verma, N. K., Lamb, D. W., Reid, N., \& Wilson, B. (2014). An Allometric Model for Estimating DBH of Isolated and Clustered Eucalyptus Trees from Measurements of Crown Projection Area. Forest Ecology and Management, 326, 125-132.

https://doi.org/10.1016/j.foreco.2014.04.003

Yao, W., Krzystek, P., \& Heurich, M. (2012). Tree Species Classification and Estimation of Stem Volume and DBH Based on Single Tree Extraction by Exploiting Airborne Full-Waveform LIDAR Data. Remote Sensing of Environment, 123, 368-380.

https://doi.org/10.1016/j.rse.2012.03.027 